\title{
Trace Element Studies in Three Patients and a Fetus with Menkes' Disease. Effect of Copper Therapy
}

\author{
JOHANNES L. NOOIJEN, ${ }^{(24)}$ CORNELIS J. DE GROOT, ${ }^{(2 i)}$ CORNELIS J. A. VAN DEN HAMER, LEO \\ A. H. MONNENS, JACOBUS WILLEMSE, MARTINUS F. NIERMEIJER \\ Interuniversity Reactor Institute. Delft. The Netherlands [J. L. N., C. J. A. Van den H.]; Department of Pediatrics, \\ University Hospital, Groningen. The Netherlands /C. J. de G.J; Department of Pediatrics, University Hospital. \\ Nijmegen, The Netherlands [L. A. H. M.]; Department of Childneurologv. University Hospital, Utrecht, The \\ Netherlands [J. W.]; Department of Clinical Genetics, Erasmus University, Rotterdam, The Netherlands /M. F. N.]
}

\begin{abstract}
Summary
This paper reports the results of a multielement analysis of postmortem samples of Menkes patients, of which one was untreated and two had been treated for various lengths of time with intramuscular injections of copper-EDTA. The findings have been compared with data from a Menkes fetus and from controls.

The results confirm that copper accumulates in various tissues and demonstrate a further increase in copper levels as a result of the treatment with copper-EDTA. Although no clinical improvement was observed, the levels of some copper-containing enzymes normalized during the copper therapy. Furthermore, in agreement with the identification of the copper-binding protein in the kidney as metallothionein, it was found that not only copper, but also
\end{abstract} zinc, cadmium, and mercury are trapped in this tissue.

A low copper concentration in the brain was also found in a Menkes fetus, indicating that brain damage might already have occurred before birth.

\section{Speculation}

Until recently, Menkes' disease was considered to be due to copper deficiency. However, the symptoms are more typical of a storage disease in which copper is irreversibly trapped in some tissues, in particular in the kidneys, by metallothionein. This abnormal storage pattern gives rise to copper deficiency elsewhere in the organism, particularly in the brain where it may cause irreversible damage in the foetus. Parenteral administration of copper does not lead to clinical improvement. The only "therapy" that seems feasible at present is tracing the carriers of the disease and advising abortion when prenatal diagnosis indicates a male fetus carrying the disease.

Menkes' disease was described for the first time in $1962(19)$ as an X-linked recessive disorder. It is characterised by mental and motor retardation associated with other anomalies (kinky hair. tortuosity of the arteries, bone lesions, and hypothermia) and results in early death. These anomalies are the result of a disturbed copper metabolism $(11,12)$, and in particular, according to the latest evidence (10), to an impaired copper absorption in the gastrointestinal tract together with an abnormal copper distribution in various tissues $(12,17)$. There is, for instance, an increased copper concentration in the kidneys and intestinal mucosa and a decreased copper concentration in blood plasma, liver, and brain tissue.

Experiments with Brindled mice, which can be used as a model for Menkes patients, have shown that the increased uptake in the kidneys is due to an increased formation of metallothionein (21. 22). As a result, copper is trapped and is, therefore, not available for normal metabolism. This leads to a low plasma copper level, decreased uptake in the liver, reduced formation of ceruloplasmin, and a deficiency of a number of copper-containing enzymes.

Because of the known copper deficiency, many attempts have been made to influence the course of the disease by the parenteral administration of copper derivatives. However, the results have been generally disappointing (8).

This paper reports that results of a multielement analysis of postmortem samples of Menkes patients, of which one was untreated and two had been treated for various lengths of time with intramuscular injections of copper-EDTA. They have been compared with data found for a Menkes fetus and with controls.

\section{MATERIALS AND METHODS}

Postmortem tissue samples from the three Menkes patients, a Menkes fetus, and the controls were taken and stored in acidtreated tubes at $-20^{\circ} \mathrm{C}$ to await analysis. To prevent contamination, the instruments used to handle the samples were washed with a $1 \%$ solution of ethylenediaminetetraacetic acid ( $\mathrm{Na}:-$ EDTA) and rinsed with demineralized water before use. Trace element concentrations were measured by destructive neutron activation analysis. Tissue samples of about $1 \mathrm{~g}$ wet weight were put into thoroughly cleaned quartz vials (Spectrosil: Thermal Syndicate Ltd., Wallsend, Tyne and Wear. NE28 6DG. England) and lyophilized to reduce pressure buildup during irradiation. The vials were then sealed. Irradiation was carried out for $12 \mathrm{hr}$ in the highflux facility of the Hoger Onderwijs Reactor at the I.R.I.. Delft (thermal neutron flux, approximately $10^{13} \mathrm{n} \cdot \mathrm{cm}^{-2} \cdot \mathrm{sec}^{-1}$ ). After a cooling period of $60 \mathrm{hr}$ the irradiated samples were processed in an automated chemical separation apparatus, as described by Tjioe et al. (24). This procedure consists of destruction with sulfuric acid and hydrogen peroxide, distillation of the volatile elements with hydrobromic acid. and chromatography of both distillate and residue over Dowex $2 \times 8$ anion-exchanger columns. The fractions thus obtained were counted in a $3 \times 3$-inch NaI(T1) well-type scintillation detector. Because the gamma spectra are not complex, a simple computerized peak-area calculation was applied. The accuracy and precision were regularly tested against a standard reference material, the SRM-1577 Bovine Liver from the National Bureau of Standards, Washington D. C. With this technique, the following elements were measured: arsenic, cadmium, cobalt, copper, iron, molybdenum, mercury, selenium, and zinc. All metal concentrations are reported on a wet weight basis.

Plasma copper, urine copper, and spinal fluid copper concentrations were determined by flameless atomic absorption spectrometry. Ceruloplasmin was measured immunologically by the Mancini technique using M-Partigen plates obtained from Behringwerke AG. Marburg. 


\section{CASE REPORTS}

\section{CASE I (DEPARTMENT OF CHILDNEUROLOGY, UNIVERSITY} HOSPITAL, UTRECHT

M. v. B. was born on February 25, 1973 after a 9-month pregnancy. His birthweight was $3500 \mathrm{~g}$, and his length was $49 \mathrm{~cm}$. Pregnancy and delivery were uneventful. He was the youngest child of seven. The sixth child, also a boy, died at the age of 7 months of pneumococcal meningitis. Before this terminal illness, he was severely retarded and had suffered from incurable epilepsy since the age of 2 months. At that time, the results of a cerebral encephalogram were found to be normal. Cerebral angiography revealed tortuosity of the vessels. At postmortem, detailed neuropathologic examination showed specific cerebral and cerebellar features of Menkes' disease. A brother of the mother had died of epileptic fits at the age of 6 months.

M. v. B. showed hypothermia $\left(31.5^{\circ} \mathrm{C}\right)$ at the age of $2 \mathrm{wk}$ and subsequently developed epileptic seizures, at first right sided, at the age of 2 months. Motor and mental development were initially normal, but from the age of 2 months he regressed rapidly to the neonatal level. On admission at the age of 4 months, the social awareness had disappeared. There was hypotonia with maximal headlag. The hair was dark and short and felt steely. Microscopy of the hair showed pilli torti and trichorrhaxis nodosa. The head was of the scaphocephalic type and large; its circumference was $45.5 \mathrm{~cm}$ (P 98). Subsequently, the circumference increased pathologically. During following months, a spastic tetraparesis developed, resulting in a decorticate state at the age of 9 months. In the course of the next year, a decerebrate state developed.

Radiologic investigations showed that the vertebral column and the extremities were normal. Encephalograms revealed a symmetric widening of the lateral and the third ventricles. The aquaeduct. the fourth ventricle, and the sulci were not filled with air. Abdominal and cerebral angiography (Seldinger) revealed a general severe tortuosity of vessels. The left vertebral artery was obstructed, and the inferior vena cava was missing.

The sural nerve biopsy showed severe demyelination and proliferation of endoneurium.

Routine investigation of the blood (including uric acid) showed normal values. However, repeatedly, a low plasma iron concentration was found ( $4 \mu$ moles/litre) with a low $(5 \%)$ degree of saturation, Haemoglobin was normal. Cytochrome $c$ oxidase activity in leukocytes was 0.06 and 0.08 nmole cytochrome $c$ per min and per $\mathrm{ml}$ blood. The copper and ceruloplasmin values are shown in Table 1
Attempts to transfer ${ }^{64} \mathrm{Cu}$, administered orally in the form of various complexes, through the intestinal wall were not successful. No parenteral treatment with $\mathrm{Cu}$ EDTA was given. Notwithstanding frequent epileptic seizures of several types (tonic-clonic seizures, infantile spasms, and epileptic states), the condition remained mainly unchanged until death due to pneumonia occurred at the age of 4 years. The findings at postmortem corresponded with Menkes' disease.

\section{CASE II (DEPARTMENT OF PEDIATRICS. UNIVERSITY HOSPITAL. GRONINGEN}

J. B. was born on May 16, 1975 after 40 wk of pregnancy. His birthweight was $3750 \mathrm{~g}$. Pregnancy and delivery were uneventful. He was the second child in the family. The first child, also a boy, died at the age of 17 months. His illness was characterized by neurologic abnormalities starting at the age of 4 months, but no definite diagnosis could be made. The growth and development of J. B. was normal until the age of 2.5 months. Then a gradual deterioration occurred. At the age of 3.5 months, he lost the ability to laugh, and feeding problems (vomiting) started. He then was referred for treatment.

On admission. he showed low-grade epilepsy. The circumference of the head was $41.5 \mathrm{~cm}$. His hair showed a woolly appearance but had a steely feeling. Neurologic examination showed a decreased muscular tone. There were uncoordinated eye movements. Reflexes were absent or low. There was a total headlag, and in sitting position, his head control was poor. Furthermore, he showed irregular jerky movement of the limbs.

Radiologic investigations showed epiphyseal and metaphyseal abnormalities. A delay in ossification of the proximal epiphysis of the femur was observed. In the metaphyses of the long bones, irregular ossification was also seen. Routine investigation of the blood showed normal values. A low plasma iron concentration was repeatedly found (5.2 $\mu$ moles/litre) and a low (7\%) degree of saturation. The haemoglobin levels were normal.

The copper and ceruloplasmin values are given in Table 1. Cytochrome $c$ oxidase activity in the leukocytes was low.

From the age of 9 months, the patient was treated with intramuscular injections of $1 \mathrm{mg} \mathrm{Cu}$-EDTA twice weekly. During this treatment, hair growth improved, and the texture of the hair became more woolly. The blood ceruloplasmin concentration and the serum copper concentration rose to within normal values. The spinal fluid copper concentration did not change, but remained low. Clinically, no improvement was observed. The reflexes re-

Table 1. Plasma copper, ceruloplasmin, urine copper, and spinal fluid copper concentrations of Menkes patients I, II, and III before and during copper therapy

\begin{tabular}{|c|c|c|c|c|c|}
\hline Copper therapy & Date of sampling & $\begin{array}{l}\text { Plasma copper } \\
(\mu \mathrm{g} / \mathrm{ml})\end{array}$ & $\begin{array}{c}\text { Ceruloplasmin } \\
(\mathrm{mg} / 100 \mathrm{ml})\end{array}$ & $\begin{array}{l}\text { Urine copper } \\
(\mu \mathrm{g} / 24 \mathrm{hr})\end{array}$ & $\begin{array}{l}\text { Spinal fluid copper } \\
(\mu \mathrm{g} / \mathrm{ml})\end{array}$ \\
\hline \multicolumn{6}{|l|}{ Case I (born 2/25/73) } \\
\hline No & $11 / 08 / 73$ & 0.27 & 4.6 & 38 & \\
\hline No & $01 / 14 / 74$ & 0.28 & 6.1 & & \\
\hline \multicolumn{6}{|l|}{ Case II (born $5 / 16 / 75$ ) } \\
\hline No & $01 / 18 / 76$ & 0.06 & n.d.' & $9-18^{2}$ & $0.01-0.02$ \\
\hline Started at $01 / 24 / 76$ & $02 / 19 / 76$ & 1.66 & 19.6 & & 0.02 \\
\hline \multirow[t]{2}{*}{ Up to $08 / 30 / 76$} & $03 / 08 / 76$ & 0.67 & & & \\
\hline & $05 / 16 / 76$ & 0.94 & & & 0.02 \\
\hline \multicolumn{6}{|l|}{ Case III (born 4/30/74) } \\
\hline No & & 0.25 & 2.3 & 11.3 & \\
\hline Started at $12 / 10 / 74$ up to his death & See Figure 1 & See Figure I & See Figure 1 & & $0.01-0.02$ \\
\hline Normal values & & $0.8-1.6(25)$ & $\begin{array}{l}22-39(2) \\
19-36(25)\end{array}$ & $6-17(25)$ & $0.02-0.07^{3}$ \\
\hline
\end{tabular}

\footnotetext{
'n.d., not detectable.

"Calculated from values of 0.03 and $0.06 \mu \mathrm{g}$ copper per $\mathrm{ml}$ urine and assuming a daily excretion of about $300 \mathrm{ml}$.

"Measured by flameless atomic absorption spectrometry by A. M. W. van der Meer, I. R. I., Delft. 1978.
} 
mained low. The patient's general condition gradually worsened, and he died at the age of 2 years.

\section{CASE III (DEPARTMENT OF PEDIATRICS, UNIVERSITY HOSPITAL. NIJMEGEN)}

S. K., a male, was born on April 30, 1974 of a second pregnancy to young unrelated parents after 42 wk of gestation. Pregnancy and delivery were uneventful; the birthweight was $2800 \mathrm{~g}$.

No cases of Menkes' disease had been recognized in either family. A sister was normal. Apart from periods of vomiting, there was no problem during the immediate neonatal period. When 2

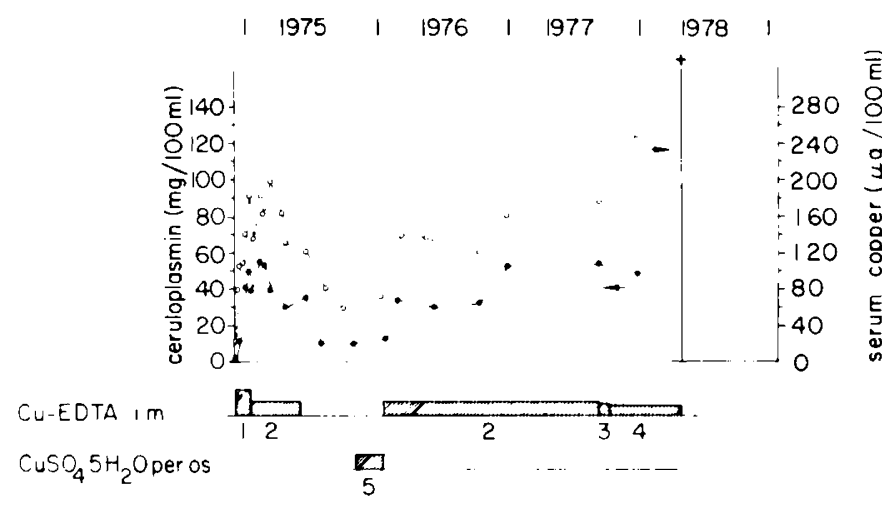

Fig. 1. Serum copper and ceruloplasmin values for patient $\mathbf{S}$. K. (case III) during copper therapy. Various doses of copper as copper-EDTA (intramuscular) or $\mathrm{CuSO}_{4} \cdot 5 \mathrm{H}_{2} 0$ (per os): (1) $1 \mathrm{mg}$ copper per day; (2) 2 mg copper 2 times per week: (3) $1.5 \mathrm{mg}$ copper 2 times per week; (4) $2 \mathrm{mg}$ copper 1 time per week, $5.4 \mathrm{mg}$ copper per day. months old, he was smiling responsively and was visually responsive.

At the age of 2.5 months, after a period of diarrhoea and vomiting, convulsions started, primarily left sided. They could not be completely controlled even by use of several anticonvulsants.

A mastoidectomy with drainage of pus was performed.

At the age of 4 months, the patient was admitted for treatment. The physical examination showed an infant with severe hypotonia, poor head control, and frequent fits. He did not respond to light, and reflexes were low, although the pupils reacted adequately. The scalp hair was steely, scanty, and fair. Microscopically, the hair showed twisting and segmental narrowing. Spur formation at the distal end of both femora was also observed.

Hypothermic periods became evident. Routine investigation of the blood showed normal values, except that a repeatedly low plasma iron concentration was found ( 7.6 to $9.4 \mu \mathrm{moles} /$ litre), and the degree of saturation was low (11 to $14 \%$ ). Haemoglobin values were normal.

Copper and ceruloplasmin values are shown in Table $I$ and Figure 1. From the age of 7 months, the patient was treated with intramuscular injections of copper-EDTA. One mg copper was given daily during $3 \mathrm{wk}$; later, $2 \mathrm{mg}$ twice a week, and finally 2 mg once a week were administered. After this treatment, a normal concentration of plasma-copper and ceruloplasmin was maintained until death (see Fig. 1). Cytochrome $c$ oxidase activity in the leukocytes increased 1.5 -fold to 0.31 nmole cytochrome $c$ per min per $\mathrm{ml}$ blood. Further, no clear benefit from the treatment could be observed.

Microcephaly became evident. The patient remained very hypotonic with deficient head control, but with brisk deep tendon reflexes. Visual fixation was never present. Partial control of the seizures was achieved with phenobarbital, diphantoine, and diazepam. The only evidence of an effect due to the copper was darkening of the hair shortly after the start of the treatment. The patient died at the age of 4 years due to a respiratory infection.

Table 2a. Concentrations' of copper, zinc, cadmium, and mercury in various tissues of Menkes patients $I, I I$, and III and the control (C)

\begin{tabular}{|c|c|c|c|c|c|c|c|c|c|c|c|c|c|c|c|c|}
\hline \multirow[b]{2}{*}{ Tissue } & \multicolumn{4}{|c|}{ Copper (ppm) } & \multicolumn{4}{|c|}{ Zinc (ppm) } & \multicolumn{4}{|c|}{ Cadmium (ppb) } & \multicolumn{4}{|c|}{ Mercury (ppb) } \\
\hline & 1 & 11 & III & C & 1 & 11 & III & C & 1 & II & 111 & C & I & 11 & 111 & $\mathrm{C}$ \\
\hline \multicolumn{16}{|l|}{ Kidney } & 8.6 \\
\hline Cortex & 100 & 180 & 150 & 2.5 & 49 & 70 & 46 & 30 & 740 & 980 & 920 & 140 & 170 & 670 & 89 & 31 \\
\hline Medulla & & & 18 & 1.7 & & & 15 & 18 & & & 160 & 49 & & & 13 & 12 \\
\hline \multicolumn{17}{|l|}{ Brain } \\
\hline Cerebrum cortex & 0.57 & 0.86 & 1.4 & 2.3 & 14 & 20 & 9.1 & 12 & $<2.9$ & 26 & $<2.4$ & 4.1 & 4.7 & 8.1 & 3.3 & 2.4 \\
\hline Cerebellum & 0.76 & 0.86 & 1.7 & 2.0 & 12 & 18 & 9.7 & 11 & $<2.5$ & 22 & 2.2 & 4.4 & 3.1 & 6.5 & 2.4 & 2.2 \\
\hline Muscle & 2.7 & 7.3 & 9.9 & 1.2 & 39 & 64 & 53 & 54 & & 8.8 & 4.2 & $<4.4$ & & 4.2 & 2.4 & 1.8 \\
\hline
\end{tabular}

' Copper and zinc concentrations in $\mu \mathrm{g} / \mathrm{g}$ fresh weight (ppm), cadmium and mercury concentrations in $\mathrm{ng} / \mathrm{g}$ fresh weight (ppb).

Table 2b. Concentrations' of selenium, iron, molybdenum, cobalt and arsenic in various tissues of Menkes patients I, II and III and the control (C)

\begin{tabular}{|c|c|c|c|c|c|c|c|c|c|c|c|c|c|c|c|c|c|c|c|c|}
\hline \multirow[b]{2}{*}{ Tissue } & \multicolumn{4}{|c|}{ Selenium (ppb) } & \multicolumn{4}{|c|}{ Iron (ppm) } & \multicolumn{4}{|c|}{ Molybdenum (ppb) } & \multicolumn{4}{|c|}{ Cobalt (ppb) } & \multicolumn{4}{|c|}{ Arsenic (ppb) } \\
\hline & I & II & 111 & $\mathrm{C}$ & 1 & II & III & C & I & 11 & 111 & C & 1 & 11 & III & $\mathrm{C}$ & I & II & III & $\mathrm{C}$ \\
\hline Liver & 200 & 180 & 340 & 190 & 87 & 90 & & 133 & 40 & 1050 & 660 & 590 & 51 & 28 & 25 & 23 & 3.1 & $<0.43$ & 8.5 & 3.4 \\
\hline \multicolumn{21}{|l|}{ Kidney } \\
\hline Cortex & 660 & 670 & 660 & 730 & 94 & 25 & 32 & 57 & 82 & 260 & 160 & 230 & 14 & 0.40 & 8.6 & $<1.8$ & 4.6 & 4.3 & 32 & 3.1 \\
\hline Medulla & & & 210 & 320 & & & 73 & 38 & & & 57 & 83 & & & 1.9 & 1.7 & & & 1.4 & 2.2 \\
\hline \multicolumn{21}{|l|}{ Brain } \\
\hline Cerebrum cortex & 110 & 100 & 100 & 100 & 31 & 32 & 7.4 & 12 & $<1.6$ & 33 & 26 & 10 & 5.0 & 1.6 & 2.0 & $<0.64$ & $<0,14$ & 1.7 & 1.5 & 0.36 \\
\hline Cerebellum & 100 & 91 & 99 & 110 & 49 & 21 & 27 & 19 & $<1.4$ & 24 & 14 & 6.9 & 3.9 & 2.1 & 3.1 & $<1.0$ & $<0.12$ & $<0.36$ & 4.3 & 0.42 \\
\hline & & & & & & & & & & & & & & & $<0.60$ & & & & & \\
\hline Muscle & & 74 & 110 & 100 & & 34 & 17 & 9.3 & & 14 & 16 & 3.6 & & 5.2 & $<0.60$ & 1.4 & & 2.2 & 3.9 & 1.5 \\
\hline
\end{tabular}

\footnotetext{
'Iron concentrations in $\mu \mathrm{g} / \mathrm{g}$ fresh weight ( $\mathrm{ppm}$ ), selenium. molybdenum, cobalt. and arsenic concentrations in $\mathrm{ng} / \mathrm{g}$ fresh weight (ppb).
} 


\section{CONTROL C (DEPARTMENT OF PEDIATRICS, UNIVERSITY HOSPITAL, GRONINGEN)}

This subject was a boy with diabetes mellitus who had died at the age of 10 months from a septic coma. The difference in age between this subject and the three Menkes patients is open to criticism as to the correctness of comparison, in particular because neonatal liver-copper concentrations are 10 to 20 times higher than normal adult values, which are reached at an age of 6 to 12 months $(5,23)$. However, this subject appeared to have already reached the adult liver-copper value of $7 \mathrm{ppm}$.

\section{MENKES FETUS AND TWO FOETAL CONTROLS (DEPARTMENT OF CLINICAL GENETICS, ERASMUS UNIVERSITY, ROTTERDAM)}

The second child of healthy nonconsanguineous parents was a son with the symptoms indicative of Menkes' disease. The fifth pregnancy of the mother was monitored by prenatal diagnosis; amniocentesis was carried out in the 19th wk of pregnancy (Dr. M. G. J. Jahoda, Department of Obstetrics and Gynecology, University Hospital Dijkzigt, Rotterdam), and chromosome analysis in cultured amniotic fluid cells showed a male karyotype $(46, X Y)$ (Dr. E. S. Sachs, Department of Cell Biology and Genetics, Erasmus University, Rotterdam). ${ }^{64} \mathrm{Cu}$ incorporation studies in the cultured amniotic fluid cells (Dr. N. Horn, The Kennedy Institute, Copenhagen, Denmark) showed an abnormally elevated level, indicative of an affected fetus. At the parents' request, the pregnancy was terminated by intraamniotic prostaglandin injection in the 23rd wk.

A male fetus was delivered, weighing $1060 \mathrm{~g}$ with a crown-heel length of $38 \mathrm{~cm}$. Fetal tissues were analysed for trace elements. As controls, fetal tissues obtained from foetuses resulting from selective termination of pregnancy for nonmedical indications at 15 and 18 wk were used.

\section{RESULTS}

For patient I, who was not treated with copper, copper levels were decreased in liver and brain tissue and increased in muscle, spleen, jejunum, and especially in the kidney-cortex (40-fold) compared with control $\mathrm{C}$ (see Tables $2 a$ and 3 ).

As a result of copper therapy (patients II and III), copper levels increased in liver, kidney-cortex, brain, muscle, and spleen. A comparable increase could not be measured in the pancreas, skin, heart, and thalamus (Table 3).

In the kidney-cortex zinc, cadmium, and mercury concentrations were found to be increased in both treated and untreated patients (see Table $2 a$ ). For the elements selenium, iron, molybdenum, cobalt, and arsenic (Table $2 b$ ), no such large and consistent differences between patients and control were observed, al- though the behaviour of molybdenum in the untreated patient requires further evaluation. The comparison was hampered by the fact that in some tissues the trace element concentrations are below the detection limit.

In Table 4, copper and zinc concentrations in one Menkes fetus and two unaffected fetusses $\left(C_{1}\right.$ and $\left.C_{2}\right)$ are presented and compared with data reported by Damsgaard and Heydorn (9) and Heydorn et al. (15) for a Menkes fetus and control fetuses. Liverand brain-copper concentrations in the Menkes fetus were decreased, whereas those in kidney, muscle, spleen, heart, and placenta are increased in agreement with the data found in the untreated postnatal Menkes patient. Heydorn found the same abnormal copper distribution, except for a higher copper level in brain tissue.

Abnormalities were also found in the zinc distribution in the Menkes fetus, where a decreased concentration was observed in liver and kidney and an increased concentration in muscle, but normal concentrations in some other tissues.

\section{DISCUSSION}

Results found for the copper distribution over the various tissues for patient I (see Tables $2 a$ and 3 ), who had not been treated parenterally with copper, confirm those of other authors $(12,17)$. The low copper value in the brain tissue may be related to the neurologic symptoms and the histologic changes in this tissue (3). The kidney, and in particular its cortex, has by far the highest copper concentration. This abnormal distribution of copper, especially in the kidneys, was also found in Brindled mice, used by Prins as a model for Menkes' disease (21).

The intramuscular injection of copper-EDTA in Menkes patients (see data for patients II and III in Tables $2 a$ and 3 ) certainly influenced the copper distribution; plasma copper and ceruloplasmin were normalized (Fig. 1; Table 1); copper concentrations in

Table 3. Copper and zinc concentrations ${ }^{1}$ in some other tissues of Menkes patients $I, I I$, and $I I I$ and the control (C)

\begin{tabular}{|c|c|c|c|c|c|c|c|c|c|}
\hline \multirow[b]{2}{*}{ Tissue } & \multicolumn{4}{|c|}{ Copper (ppm) } & \multirow{2}{*}{$\begin{array}{c}\text { Normal } \\
\text { values }\end{array}$} & \multicolumn{4}{|c|}{ Zinc (ppm) } \\
\hline & I & II & III & $\mathrm{C}$ & & I & II & III & $\mathrm{C}$ \\
\hline Spleen & 6.9 & 12.7 & & & $0.6-3.2(13)$ & 22 & 23 & & \\
\hline Jejunum & 11 & 8.7 & & 1.2 & $1.47(17)$ & 28 & 18 & & 9.7 \\
\hline Pancreas & & 6.1 & & & $0.5-4.6(13)$ & & 50 & & \\
\hline Skin & & 9.7 & & & $2.4-4.0(13)$ & & 48 & & \\
\hline Heart & & 5.8 & 6.1 & 3.6 & & & 30 & 25 & 27 \\
\hline Thalamus & & & 1.7 & 4.1 & & & 16 & 12 & 9.8 \\
\hline
\end{tabular}

Table 4. Copper and zinc concentrations ${ }^{1}$ in tissues of a Menkes fetus and of two controls, $C_{1}$ and $C_{2}$

\begin{tabular}{|c|c|c|c|c|c|c|c|c|c|}
\hline \multirow[b]{2}{*}{ Tissue } & \multicolumn{3}{|c|}{ Copper (ppm) } & \multirow[b]{2}{*}{$\begin{array}{c}\text { Heydorn et al. } \\
\text { (15) }\end{array}$} & \multirow[b]{2}{*}{ Normal range (9) } & \multicolumn{4}{|c|}{ Zinc (ppm) } \\
\hline & Fetus & $C_{1}$ & $C_{2}$ & & & Fetus & $C_{1}$ & $\mathrm{C}_{2}$ & $\begin{array}{r}\text { Normal } \\
\text { range (9) }\end{array}$ \\
\hline Liver & 2.8 & 42 & 34 & 11.8 & $29-37$ & 89 & 321 & 245 & $72-286$ \\
\hline Kidney & 5.9 & 0.88 & 0.69 & 17.3 & $0.52-1.14$ & 7.2 & 13 & 13 & $9.0-11.3$ \\
\hline \multicolumn{10}{|l|}{ Brain } \\
\hline $\begin{array}{l}\text { Cerebrum } \\
\text { Cerebellum }\end{array}$ & 0.17 & 0.52 & 0.45 & 1.04 & $0.27-0.52$ & 4.2 & 6.6 & 6.4 & 4.6-5.7 \\
\hline $\begin{array}{l}\text { Cerebellum } \\
\text { Muscle }\end{array}$ & $\begin{array}{l}0.050 \\
1.7\end{array}$ & 0.29 & 0.25 & 2.57 & $0.43-0.99$ & $\begin{array}{l}0.84 \\
18\end{array}$ & 11 & 9.5 & $6.9-17.0$ \\
\hline Spleen & 8.8 & 1.9 & 0.62 & 15.4 & $0.62-1.27$ & 18 & 21 & 13 & $9.5-21.0$ \\
\hline Heart & 1.7 & & 0.68 & & & 24 & & 16 & \\
\hline Skin & 2.6 & 0.57 & & & & 16 & 9.1 & & \\
\hline Duodenum & 6.4 & & 6.2 & & & 40 & & 32 & \\
\hline Placenta & 12 & & 0.86 & 14.5 & & 15 & & 8.5 & \\
\hline
\end{tabular}

${ }^{1}$ Concentrations in $\mu \mathrm{g} / \mathrm{g}$ fresh weight $(\mathrm{ppm})$. 
kidney, spleen, and muscle were further increased. However, no increase of copper was found in the jejunum or in the pancreas, skin, heart, and thalamus. Also, the spinal fluid-copper remained unchanged; the shortage of copper in the liver and brain tissues was more or less compensated.

The increase of some copper concentrations indicates that the trapping of copper by the kidneys and some other tissues is less complete under conditions of copper therapy (i.e., and increased supply to the body), either as a result of a saturation effect or because of a limited uptake rate. The increase in copper concentration in the liver after copper therapy leads to copper becoming available for incorporation in ceruloplasmin, as has also been demonstrated by the oral ${ }^{64} \mathrm{Cu}$-loading test $(25)$ an effect that is reversed upon discontinuation of the copper therapy (Fig. 1). Copper concentration in the cerebrum and cerebellum increased. and cytochrome $c$ oxidase activity in leucocytes became normal, but no neurologic or clinical improvements were observed, suggesting that irreversible damage had already occurred.

The results show that of the various elements analysed (Table $2 a$ and $2 b$ ), cadmium, mercury, and zinc in the kidney cortex, appear to behave similarly to copper. This is in agreement with the presence of large amounts of metallothionein, as found by Prins in Brindled mice, which has a strong binding capacity for these elements (7)

Prins (22) has further shown that in Menkes' disease the cause of these large amounts of renal metallothionein, which is normally present in only minor quantities, is an abnormal regulation of its synthesis. Although a build up of cadmium and mercury is also observed in healthy human kidneys with age $(1,14)$, the extreme buildup of these elements in Menkes kidneys is clearly shown by comparison with data from the control subject. The results of Chan et al. (6) are in accordance with these findings. They reported and increased uptake of cadmium in cultured skin fibroblasts obtained from Menkes patients.

In the kidney cortex, the concentrations of the other elements specified in Table $2 b$ are approximately normal. This is in agreement with the fact that metallothionein, as far is known at the present, has no affinity for these metals.

The results obtained from the Menkes fetus (see Table 4) indicate that the disturbed copper metabolism already leads to a deviating copper distribution during the prenatal period. This could mean that incurable damage already occurs before birth. This is confirmed to some extent by work of Daish et al. (8), who was unable to achieve general improvements when starting copper therapy as early as $3 \mathrm{wk}$ after birth. The prenatal defect in copper metabolism was also confirmed by the excessive uptake of ${ }^{64} \mathrm{Cu}$ in cultured amniotic fluid cells of the fetus, which Horn (16) found to be characteristic for Menkes' disease. Metallothionein was probably responsible for this copper accumulation (18). These findings are supported by Beratis et al. (4), who reported an increased binding of ${ }^{\text {tit }} \mathrm{Cu}$ by a 10,000 molecular weight species in cultured skin fibroblasts from Menkes patients. From a comparison of the data from the fetus and the untreated patient $I$, it is obvious that the copper concentration in the kidneys is further increased after birth. This confirms that copper absorption through the intestinal tract, although probably impaired, is still possible.

The placenta of the Menkes fetus also showed an increased copper concentration. Because no differentiation between maternal and fetal tissue was made and the heterozygous maternal tissue only partly consists of cells which exhibit the Menkes defect (20) the true value of the fetal part of the placenta must have been considerably higher. Although much copper is trapped in the fetal part of the placenta, obviously enough copper was able to escape from or to circumvent the trap and find its way to the fetus. This is somewhat similar to the situation in the intestinal wall in Menkes' disease, where the copper is partly trapped, although some is passed on to the blood.

\section{CONCLUSIONS}

(1) Published data concerning anomalies in copper distribution in various tissues of Menkes patients were largely confirmed. An increased copper content was found in many tissues, especially in the kidneys, but a decreased value was found in liver and brain tissue.

(2) The deviating copper distribution in various tissues was also found in a Menkes fetus. This suggests that incurable damage already occurs before birth, even though the first neurologic deviations generally become apparent at the age of 2 months.

(3) Copper, administered parenterally to Menkes patients, tends to further increase the copper level in copper-accumulating tissues (e.g., the kidneys) and to normalize copper concentrations in otherwise copper-deficient tissues like the liver. However, no general remissions were observed.

(4) Increased cadmium, mercury, and zinc concentrations were found in the kidney cortex, corresponding to the identification of the copper-accumulating protein in this tissue as metallothionein (22).

\section{REFERENCES AND NOTES}

1. Anke, M., and Scheider, H. J.: Der Zink. Kadmium, und Kupferstoffwechsel des Menschen. Arch. Exp. Veterinaer Med., 25: 805 (1971).

2. Aoki. T., and Nakahashi, M.: New screening method for Wilson's disease and Menkes' kinky-hair disease. Lancet. 1140 (1977).

3. Barnard. R. O.. Best. P. V.. and Erdohazi. M.: Neuropathology of Menkes disease. Dev. Med. ('hild Neurol.. 20): 586 (1978).

4. Beratis, N. G.. Price. P., LaBadie. (;.. and Hirschhorn. K.: "'Cu melabolism in Menkes and normal cultured skin fibroblasts. Pediatr. Res.. 12: 699 (1978).

5. Bruckmann, G., and Zondek. S. (i.: Iron. copper, and manganese in human organs at various ages. Biochem. J., 3.3: 1845 (1939).

6. Chan. W. Y., Garnica. A. D., and Rennert. O. M.: Cell culture studies of Menkes kinky hair disease. Clin. Chim. Acta, 88 : 495 (1978).

7. Cherian. M. G., and Goyer. R. A.: Minireview: melallothioneins and their role in the metabolism and toxicity of metals. Life Sci., 23: I (197X).

8. Daish. P.. Wheeler. E. M.. Roberts. P. F., and Jones, R. D.: Menkes's syndrome: report of a patient treated from 21 days of age with parenteral copper. Arch. Dis. Child.. 53: 956 (1978).

9. Damsgaard, E.. and Heydorn. K.: Simultaneous determination of arsenic, copper. manganese. selenium, and zinc in biological materials by neutron activation analysis. (Risø report 326. Roskilde. Denmark. 1976).

10. Danks, D. M.: Copper transport and utilisation in Menkes' syndrome and in mottled mice. Inorg. Perspect. Biol. Med., l: 73 (1977).

11. Danks. D. M.. Campbell. P. E.. Stevens. B. J., Mayne. V., and Cartwright. E. Menkes kinky hair syndrome: an inhereted defect in copper absorption with widespread effects. Pediatrics, 50): 188 (1972).

12. Danks. D. M. Stevens, B. J.. Campbell. P. E.. Walker-Smith. J. M.. Blomfield. J., and Turner, B.: Menkes' kinky hair syndrome. Lancet. I: II(0) (1972).

13. Evans. J. Newman. S.. and Sherlock. S.: Liver copper levels in intrahepatic cholestasis of childhood. Gastroenterology. $75: 875$ (1978).

14. Fisher. H.. and Weigert. P.: Die Schwermetalle Kupfer. Quecksilber. Mangan. und Zink in menschlichen Organen. Öff. (iesundh. Wesen.. 39: 269 (1977).

15. Heydorn. K.. Damsgaard, E.. Horn. N.. Mikkelsen. M., Tygstrup. I.. Vestermark. S.. and Weber. J.: Extra-hepatic storage of copper: a male foetus suspected of Menkes disease. Humangenetik. 29: 171 (1975).

16. Horn. N.: Copper incorporation studies on cultured cells for prenatal diagnosis of Menkes' disease. Lancet. 1: 1156 (1976).

17. Horn. N.. Heydorn, K.. Damsgaard. E.. Tygstrup, I., and Vestermark. S.: Is Menkes' syndrome a copper storage disorder? Clin. (jenet.. 14: 186 (197\%).

18. Jonker. P.: (unpublished results).

19. Menkes, J. H.. Alter, M.. Steigleder, (j. K.. Weakley. D. R.. and Sung. J. H.: A sex-linked recessive disorder with retardation of growth. peculiar hair, and focal cerebral and cerebellar degeneration. Pediatrics, 29: 764 (1962).

20. Mooij. P. D.. Niermeijer. M. F.. and Kleijer. W. J.: Heterosygote detection in Xlinked Menkes' kinky hair syndrome using cultured tibroblasts. Abstracts of the 18th Dutch Federative Meeting. p. 77, (1977).

21. Prins. H. W.. and Van den Hamer. C. J. A.: Primary biochemical defect in copper metabolism in mice with a recessive $X$-linked mutation analogous to Menkes disease in man. J. Inorg. Biochem.. I): 19 (1979).

22. Prins, H. W and Van den Hamer. C. J. A.: Abnormal copper-thionein synthesis and impaired copper utilization in mutated Brindled mice: model for Menkes' disease. J. Nutr.. 1/1): 151 (1980).

23. Sass-Kortsak. A.: Copper metabolism. Adv. Clin. (hem.. 8: 1 (1965).

24. Tjioe. P. S., de Goeij. J. J. M.. and Houtman. J. P. W.: Extended automated separation techniques in destructive neutron activation analysis: application to various biological materials, including human tissues and blood. J. Radioanal. Chem.. 37: 511 (1977).

25. Van den Hamer, C. J. A.. Willemse. J.. and de Haas, G.: Copper metabolism. 
particularly in relation to Wilson's and Menkes' diseases. In: K. H. Ephraim. O. H. Yoe: Nuclear Medicine. pp. 204-209 (State University Utrecht. Utrecht. The Netherlands, 1975).

26. Williams, D. M.. Atkin, C. L.. Frens, D. B.. and Bray. P. F.: Menkes' kinky hair syndrome: studies of copper metabolism and long term copper therapy. Pediatr. Res.. 11: 823 (1977).
27. The present address of Cornelius 1. de Groot is: Department of Pediatrics, Zuiderziekenhuis. Rotterdam. The Netherlands.

28. Requests for reprints should be addressed to: Dr. J. L. Nooijen, Interuniversity Reactor Institute. Mekelweg 15, 2629 JB Delft. Netherlands.

29. Received for publication March 3, 1980

30. Accepted for publication July 29.1980 